\title{
Nutrisi Organik Sistem Hidroponik Wick Pada Tanaman Sawi dan Kangkung
}

\author{
Nurfhin Ilma Bunga \\ Program Studi Agribisnis \\ Fakultas Pertanian Universitas Kristen Tentena \\ e-mail : nbunga89@gmail.com
}

\begin{abstract}
Abstrak
Hidroponik merupakan cara bercocok tanam tanpa tanah namun bukan hanya air media pertumbuhannya. Sistem hidroponik dapat menggunakan media tanam (substrat) seperti sabut kelapa (cocopeat), arang sekam, busa (spons) ,serbuk gergaji dan sebagainya. Selain media tanam, salah satu faktor yang mempengaruhi pertumbuhan tanaman adalah nutrisi. Nutrisi adalah faktor terpenting dalam budidaya tanaman khususnya dalam system hidroponik. Untuk mendapatkan hasil yang optimal maka nutrisi tanaman harus terpenuhi. Pemberian dosis yang tepat pada larutan nutrisi dapat memberikan hasil yang produktif. Hasil penelitian menunjukan bahwa Hidroponik wick system dapat diaplikasikan pada tanaman kangkung dan sawi dengan dosis pemberian nutrisi pada tanaman kangkung sebesar $20 \mathrm{ml} / \mathrm{L}$ dan $10 \mathrm{ml} / \mathrm{L}$ untuk tanaman sawi.
\end{abstract}

Kata kunci : Hidroponik ; Nutrisi

\section{Pendahuluan}

Kebutuhan sayuran daun seperti sawi dan kangkung cenderung meningkat sejalan dengan meningkatnya kesadaran masyarakat akan pentingnya gizi untuk mendukung pola hidup sehat. Produksi sayuran sawi dan kangkung telah menjadi mata dagangan sehari-hari diberbagai tempat dengan harga yang mudah dijangkau oleh masyarakat. Sawi dan kangkung dapat diolah menjadi berbagai jenis masakan. Selain sebagai sumber vitamin A serta unsur gizinya, tanaman kangkung juga dapat berfungsi menenangkan saraf dan sebagai bahan baku obat tradisional untuk penyakit sembelit. Sama halnya dengan tanaman kangkung, tanaman sawi berguna dalam pengobatan berbagai penyakit seperti mencegah kanker, hipertensi, penyakit jantung, membantu kesehatan system pencernaan, serta menghindarkan ibu hamil dari anemia (Cahyono, 2013). Walaupun harga tanaman sawi dan kangkung relatif murah, namun jika dibudidayakan secara intensif dan berorientasi kearah agribisnis akan 
memberikan keuntungan yang besar bagi petani. Tanaman sawi dan kangkung dapat dibudidayakan dengan sistem hidroponik.

Hidroponik merupakan cara bercocok tanam tanpa tanah namun bukan hanya air media pertumbuhannya, seperti makna dari kata hidro yang berarti air. Sistem hidroponik dapat menggunakan media tanam (substrat) seperti sabut kelapa (cocopeat), arang sekam, busa (spons) ,serbuk gergaji dan sebagainya. Bahan-bahan tersebut dipilih karena memiliki daya absorbsi yang tinggi. Media tanam berfungsi sebagai tempat melekatnya akar, penyangga agar tanaman tetap berdiri tegak, menjaga kelembaban dan menyimpan nutrisi yang dibutuhkan oleh tanaman. Salah satu hidroponik sederhana ialah wick system atau sering disebut dengan sistem sumbu. Teknik hidroponik wick system atau sistem sumbu mudah diaplikasikan dan murah, karena tidak membutuhkan biaya yang banyak dalam pengadaan alatnya. Hidrponik wick system dapat dibuat dari barang-barang bekas seperti botol air mineral.

Selain media tanam, salah satu faktor yang mempengaruhi pertumbuhan tanaman adalah nutrisi. Nutrisi adalah faktor terpenting dalam budidaya tanaman khususnya dalam system hidroponik. Untuk mendapatkan hasil yang optimal maka nutrisi tanaman harus terpenuhi. Pemberian dosis yang tepat pada larutan nutrisi dapat memberikan hasil yang produktif. Berdasarkan uraian diatas maka dilakukan penelitian untuk mengetahui efektivitas nutrisi organik dengan sistem hidroponik wick pada tanaman sawi dan kangkung.

\section{Tempat dan Waktu Penelitian}

\section{Metode Penelitian}

Penelitian ini dilakukan pada bulan September sampai Oktober 2019 di kebun percobaan Fakultas Pertanian Universitas Kristen Tentena.

\section{Alat dan Bahan}

Alat dan bahan yang digunakan dalam penelitian ini mencakup : alat tulis menulis, kamera untuk dokumentasi, botol bekas air mineral ukuran 1,5 liter sejumlah 30 botol untuk masingmasing kelompok, gunting/cuter, sumbu woll,tabung ukur, baki palstik, label, benih tanaman kangkung pupuk cair organik, arang sekam dan cocopeat sesuai kebutuhan.

\section{Rancangan Percobaan}

Penelitian ini menggunakan Rancangan Acak Lengkap yang terdiri dari 1 faktor yaitu dosis pemberian larutan nutrisi. Larutan 
nutrisi menggunakan pupuk cair organik dengan konsentrasi masing-masing $0 \mathrm{ml} / \mathrm{L}$ (P0), $5 \mathrm{ml} / \mathrm{L}$ (P1), 10ml/L (P2), 15ml/L (P3) dan $20 \mathrm{ml} / \mathrm{L}$ (P4) dan $25 \mathrm{ml} / \mathrm{L}$ (P5). Terdapat 6 pola perlakuan yang diulang sebanyak 5 kali, sehingga terdapat 30 satuan percobaan, untuk masing-masing tanaman yaitu sawi dan kangkung.

\section{Prosedur Penelitian}

Pembuatan Pot Hidroponik dengan model Wick system :

- Botol air mineral dbagi menjadi dua bagian dengan menggunakan cutter. Tutup botol dilubangi untuk meletakan sumbu.

- Bagian bawah botol dijadikan sebagai wadah penyimpanan larutan nutrisi, sedangkan bagian atas botol sebagai wadah penyimpanan media tanam arang sekam dan cocopeat.

\section{Penyemaian}

Benih tanaman kangkung disemaikan terlebih dahulu di tempat wadah baki plastik yang diisi dengan abu sekam yang dicampurkan dengan pasir dan dijaga kelembabannya. Setelah muncul kecambah dan berumur dua minggu bibit dipindahkan ke pot botol air mineral yang telah disiapkan.

\section{Larutan Nutrisi}

Larutan nutrisi dilarutkan sesuai dengan konsentrasi yang telah ditentukan yaitu $0 \mathrm{ml} / \mathrm{L}, 5 \mathrm{ml} / \mathrm{L}, 10 \mathrm{ml} / \mathrm{L}, 15 \mathrm{ml} / \mathrm{L}, 20 \mathrm{ml} / \mathrm{L}$ dan $25 \mathrm{ml} / \mathrm{L}$.

\section{Penggantian Nutrisi}

Penggantian nutrisi dilakukan setiap seminggu sekali pada masing-masing perlakuan.

\section{Parameter Pengamatan Tanaman}

Parameter pengamatan meliputi perhitungan tinggi tanaman, jumlah daun dan bobot segar. Pengamatan dilakukan pada 7 hari setelah tanam (HST), 15 HST, 22 HST, 28 HST, 35 HST, 42 HST.

\section{Analisis Data}

Data yang diperoleh dianalisis menggunakan uji One Way Anova untuk mengetahui apakah terdapat perbedaan pemberian berbagai dosis nutrisi terhadap tinggi, jumlah daun dan bobot segar tanaman sawi dan kangkung.

\section{Hasil dan Pembahasan}

Media tanam yang digunakan dalam penelitian ini adalah arang sekam dan sabut kelapa, dengan perbandingan $1: 1$. Arang sekam merupakan media tanam yang ideal dari hidroponik. Arang 
sekam bisa memiliki sifat poros, berstruktur gembur, subur dan dapat menyimpan air yang cukup untuk pertumbuhan tanaman, tidak mengandung organisme penyebab hama dan penyakit (BPTP,2015). Arang sekam kaya akan karbon. Arang sekam mempunyai kemampuan sebagai absorban yang mampu menekan jumlah mikroba pathogen dalam pembuatan kompos. Sehingga kompos yang dihasilkan bebas dari patogen. Arang sekam mengandung beberapa unsur hara yang dibutuhkan oleh tanaman, seperti nitrogen $(\mathrm{N})$, fosfor $(\mathrm{P})$, kalium $(\mathrm{K})$, kalsium (Ca) dan Magnesium (Mg). Secara kimia arang sekam mengandung komposisi kimia seperti pada tabel 1.

Tabel 1. Komposisi Kimia Sekam Padi

\begin{tabular}{lc}
\hline \hline \multicolumn{1}{c}{ Komponen } & Kandungan (\%) \\
\hline Menurut Suharno & \\
Kadar Air & 9,02 \\
Protein Kasar & 3,03 \\
Lemak & 1,18 \\
Serat Kasar & 35,68 \\
Abu & 17,71 \\
Karbohidrat Kasar & 33,71 \\
Menurut DTC-IPB & \\
Karbon (zat arang) & 1,33 \\
Hidrogen & 1,54 \\
Oksigen & 33,64 \\
Silika (SiO & )
\end{tabular}

Sama halnya dengan sabut kelapa (cocopeat), media tanam ini memiliki keunggulan baik dalam menyimpan air, memiliki daya serap yang tinggi, menggemburkan tanah dengan pH netral, serta menguntungkan karena dapat menyimpan pupuk cair. Didalam cocopeat juga terkandung unsure hara dari alam yang sangat dibutuhkan tanaman dan menunjang pertumbuhan akar dengan cepat sehingga baik untuk pembibitan (Artha, 2014). Sebagai media tumbuh cocopeat juga mengandung unsur-unsur hara esensial seperti kalsium (Ca), magnesium (Mg), kalium $(\mathrm{K})$, natrium (N), dan fosfor (P) (Muliwan, 2009).

\section{Pertumbuhan Tanaman Kangkung}

Tinggi Tanaman

Hasil pengamatan menunjukan tinggi tanaman yang berbeda-beda antara masing-masing perlakuan, yang ditunjukan pada gambar 1 . 


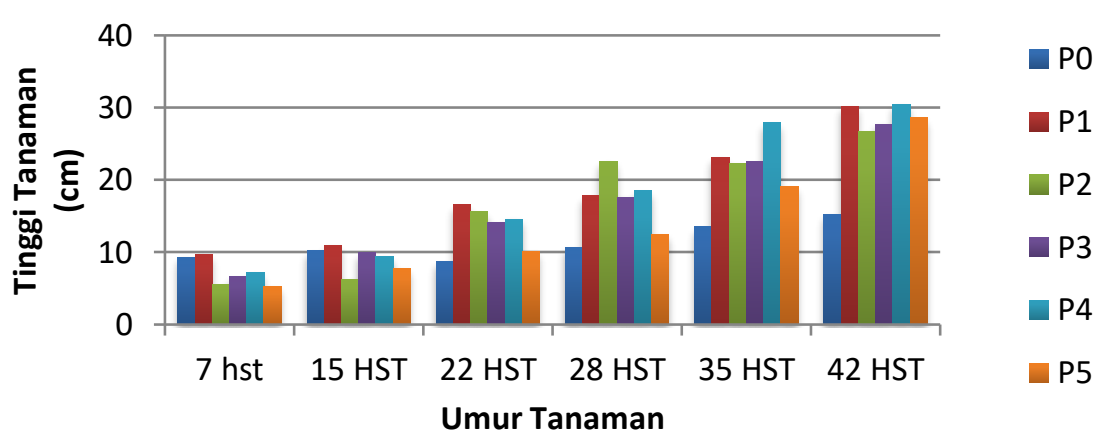

Gambar 1. Grafik Tinggi Tanaman Kangkung Setiap Minggu

Hasil pengukuran menunjukan bahwa tinggi tanaman pada umur 7 hari setelah tanam memiliki tinggi rata-rata $9.7 \mathrm{~cm}$ pada perlakukan $\mathrm{P} 1$, kemudian diikuti tinggi tanaman pada perlakuan P0 yang merupakan control dengan dosis nurisi $0 \mathrm{ml} / \mathrm{l}$, yaitu 9.28 $\mathrm{cm}$. Pada perlakuan $\mathrm{P} 4$ dengan dosis nutrisi $20 \mathrm{ml} / \mathrm{l}$, dengan tinggi tanaman $7.2 \mathrm{~cm}$, selanjutnya pada perlakuan P3 dengan dosis nutrisi $15 \mathrm{ml} / \mathrm{l}$, dengan tinggi tanaman $6.58 \mathrm{~cm}$. Selanjutnya P2 dengan dosis nutrisi tanaman $10 \mathrm{ml} / \mathrm{l}$, tinggi tanaman $5.5 \mathrm{~cm}$ dan perlakuan pada P5 dengan dosis nutrisi $25 \mathrm{ml} / \mathrm{l}$ dengan tinggi tanaman $5.5 \mathrm{~cm}$. Tinggi tanaman pada umur 42 hari setelah tanam, tinggi tanaman rata-rata yaitu $30.5 \mathrm{~cm}$ pada tanaman dengan perlakuan P4, diikuti tanaman pada perlakuan P2 yaitu $30.2 \mathrm{~cm}$. Selanjutnya perlakuan P5 dengan tinggi $28.6 \mathrm{~cm}$. Perlakuan P3 dengan tinggi rata-rata tanaman 27.74 $\mathrm{cm}$.Kemudian diikuti P2 dengan tinggi $26.7 \mathrm{~cm}$ dan P0 dengan tinggi $15.24 \mathrm{~cm}$.

Hasil analisis varians satu arah (one way anova) terhadap tinggi tanaman ditunjukan pada tabel 2. Berikut

Tabel 1. Analisis Varian Tinggi Tanaman

\begin{tabular}{lcccccc}
\hline & SS & $d f$ & MS & $F$ & $\begin{array}{c}P \text { value } \\
\text { Antar }\end{array}$ & $F$ crit \\
$\begin{array}{l}\text { Kelompok } \\
\text { Dalam }\end{array}$ & 812.33 & 5 & 162.47 & 14.24 & 0.00 & 2.62 \\
Kelompok & 273.80 & 24 & 11.41 & & & \\
\hline Total & 1086.13 & 29 & & & \\
\hline $\begin{array}{l}\text { Sumber data : diolah } \\
\text { Taraf signifikansi }\end{array}$ & sebesar & 0.00 & lebih kecil dibandingkan \\
dengan taraf signifikansi tetapan sebesar & 0.05 , dengan demikian \\
perlakuan dosis pupuk organik cair berpengaruh nyata terhadap \\
tinggi tanaman. Hasil uji lanjut dengan uji t 2 sampel independen \\
terhadap rata-rata tinggi tanaman yang merupakan hasil dari
\end{tabular}


perlakuan dosis pupuk organik cair dapat dilihat dalam tabel berikut.

Tabel 2. Rata-rata tinggi tanaman

\begin{tabular}{cc}
\hline Dosis & Rata-rata Tinggi \\
Pupuk Organik Cair & $15.24^{\mathrm{b}}$ \\
P0 $(0 \mathrm{ml} / \mathrm{L})$ & $30.2^{\mathrm{a}}$ \\
P1 $(5 \mathrm{ml} / \mathrm{L})$ & $26.7^{\mathrm{a}}$ \\
P2 $(10 \mathrm{ml} / \mathrm{L})$ & $27.74^{\mathrm{a}}$ \\
P3 $(15 \mathrm{ml} / \mathrm{L})$ & $30.5^{\mathrm{a}}$ \\
P4 $(20 \mathrm{ml} / \mathrm{L})$ & $28.6^{\mathrm{a}}$ \\
P5 $(25 \mathrm{ml} / \mathrm{L})$ & \\
\hline
\end{tabular}

Ket : angka yang diikuti huruf yang sama tidak berbeda nyata pada taraf signifikansi 0.05

Hasil uji t menunjukan bahwa perlakuan P1 sampai P5 memberikan rata-rata tinggi tanaman berbeda nyata dibandingkan dengan P0. Sedangkan perlakuan P1 sampai dengan P5 menunjukan tinggi tanaman tidak berbeda nyata.

\section{Jumlah Daun}

Hasil pengamatan menunjukan jumlah daun yang berbedabeda antar masing-masing perlakuan seperti yang ditunjukan pada gambar 2 berikut.

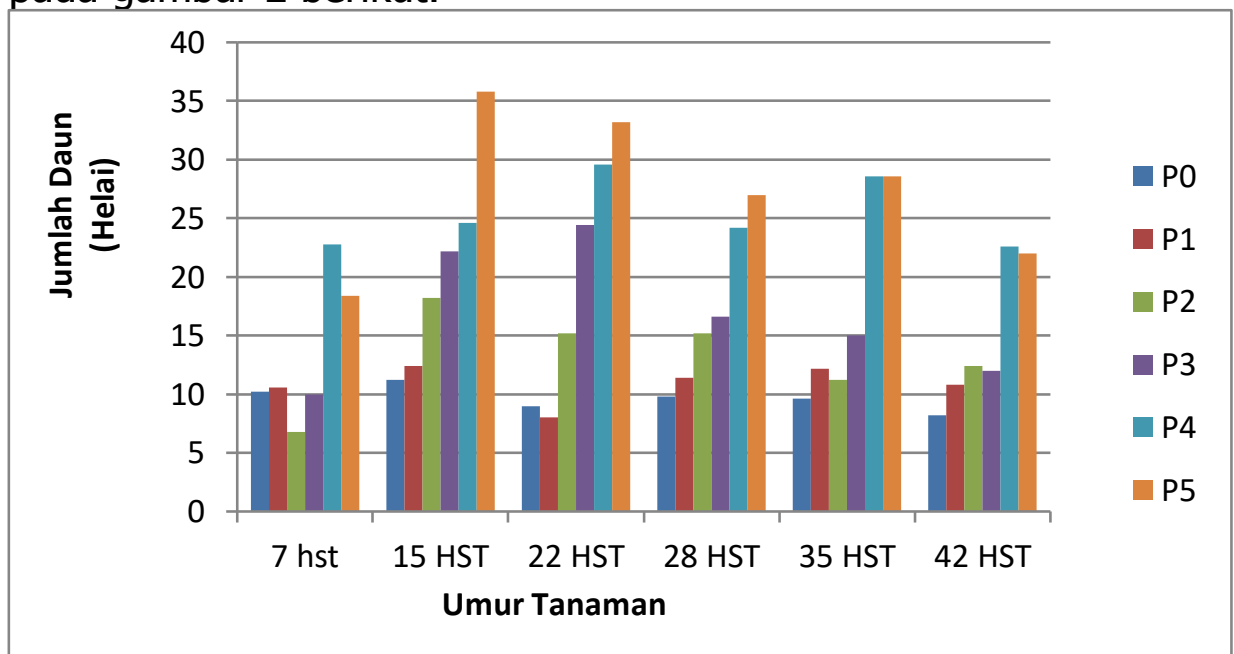

Gambar 2. Grafik Jumlah Daun Setiap Minggu

Rata-rata jumlah daun 7 hari setelah tanam untuk setiap perlakuan, dimulai dari jumlah daun terbanyak berturut-turut yaitu perlakuan P4 dengan jumlah rata-rata daun 22,6 helai, P5 jumlah rata-rata daun 22 helai, P2 jumlah rata-rata daun 12,4. Selanjutnya P3 dengan jumlah rata-rata daun 12 helai, P1 dengan jumlah rata-rata daun 10,8 helai dan terakhir pada perlakuan PO dengan jumlah rata-rata daun 8,2 helai.

Hasil analisis varian satu arah (one way anova) terhadap jumlah daun ditunjukan pada tabel 1.2 berikut. 
Tabel 2. Analisis Varian Jumlah Daun

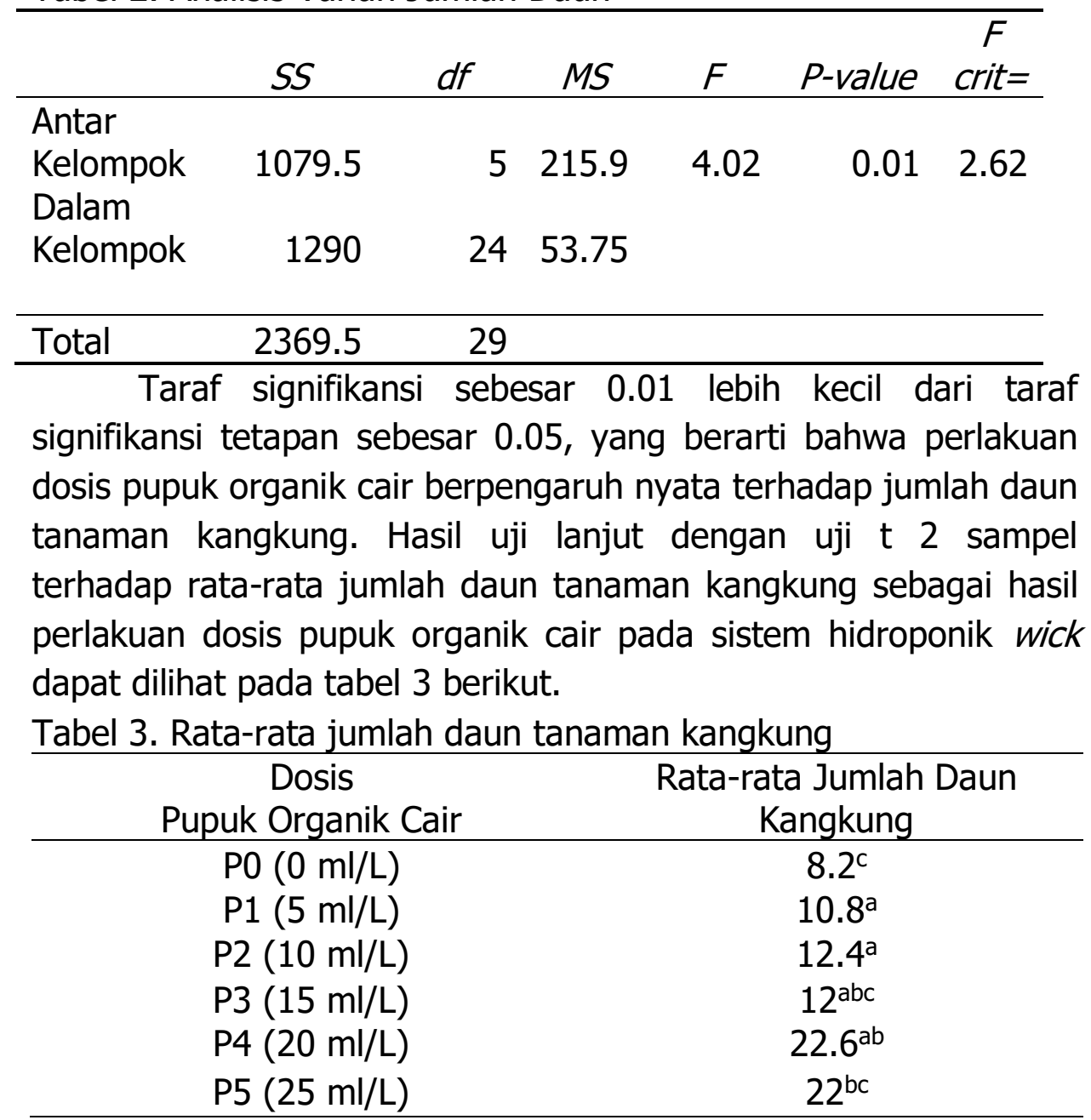

Ket : angka yang diikuti huruf yang sama tidak berbeda nyata pada taraf signifikansi 0.05

Hasil uji t menunjukan bahwa perlakuan dengan dosis pupuk organik cair P1 tidak berbeda nyata dengan perlakuan P2 namun berbeda nyata dengan perlakuan lainnya. Perlakuan dosis pupuk organic cair P4 memberikan jumlah rata-rata daun terbanyak dan berbeda nyata dengan perlakuan-perlakuan lainnya.

\section{Bobot Segar}

Bobot segar untuk tanaman kangkung dapat dilihat dalam gambar 3. Berikut 


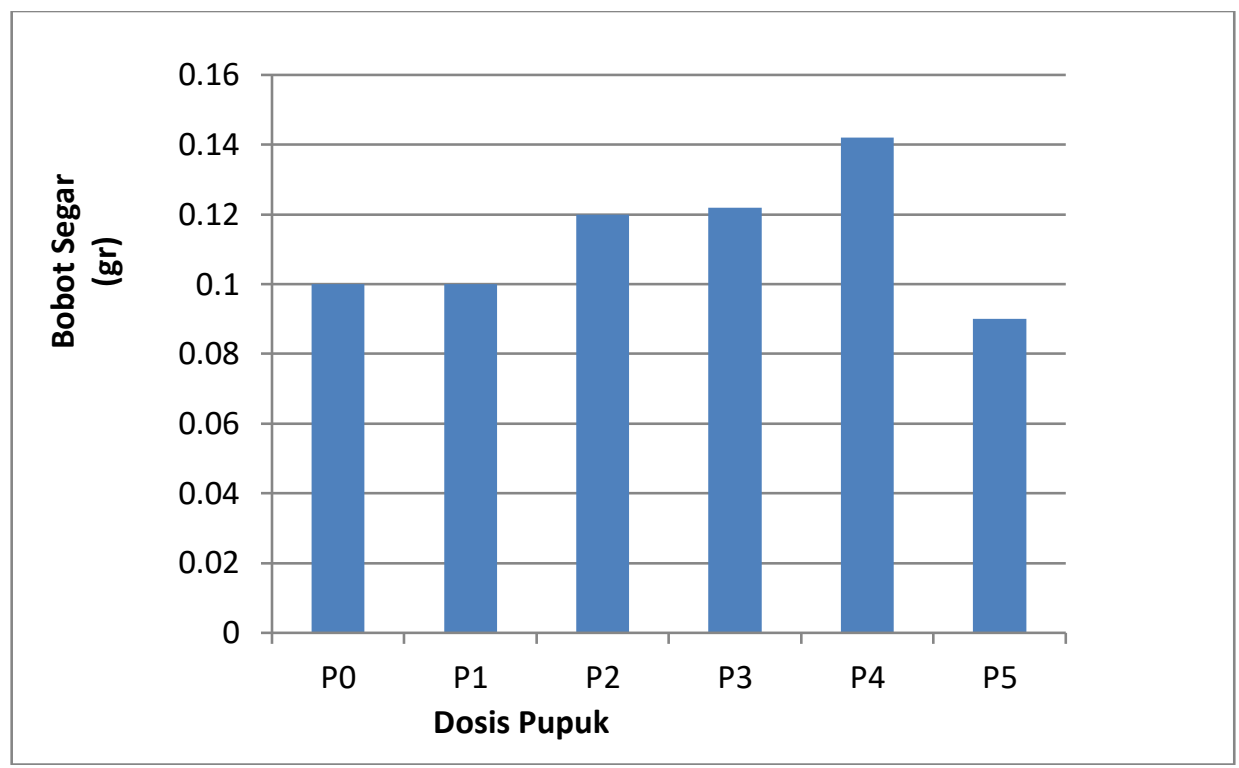

Gambar 3. Bobot segar tanaman kangkung

Berdasarkan gambar diatas dapat dilihat bahwa perlakuan P4 dengan dosis pupuk $20 \mathrm{ml} / \mathrm{L}$ menghasilkan bobot segar tanaman terberat dengan bobot sebesar $0.14 \mathrm{gr} /$ tanaman.

Berdasarkan hasil analisis dapat dilihat bahwa hidroponik dengan sistem sumbu dapat cocok diaplikasikan untuk tanaman kangkung. Penambahan dosis pupuk cair organik berpengaruh terhadap pertumbuhan tanaman kangkung. Pengaruh tersebut ditinjau dari tinggi tanaman,jumlah daun dan bobot segar tanaman. Tinggi tanaman kangkung yang diberi perlakuan berbeda nyata dengan tanaman tanpa perlakuan. Tanaman yang diberi perlakuan memiliki rata-rata tertinggi jika dibandingkan dengan tanaman tanpa perlakuan. Hal ini disebabkan oleh pertumbuhan tinggi tanaman berhubungan dengan letak meristem apikal. Meristem apikal terdapat di ujung akar dan diujung tunas yang menghasilkan pemanjangan bagi sel-sel tumbuhan (Campbell, 2003). Tanaman yang kekurangan unsur hara $\mathrm{N}$ dan $\mathrm{K}$ akan menurunkan produksi tanaman dan membuat tanaman menjadi kerdil (Franklin dan Cleon, 1995). Berdasarkan hasil penelitian ini menunjukan bahwa dosis $20 \mathrm{ml} / \mathrm{L}$ menunjukan pertumbuhan yang baik untuk tanaman kangkung. Lestari (2009), mengemukakan bahwa nutrisi yang diberikan pada tanaman harus tepat, jika kekurangan atau kelebihan akan mengakibatkan pertumbuhan tanaman dan hasil produksi kurang maksimal. 


\section{Pertumbuhan Tanaman Sawi \\ Tinggi Tanaman Sawi}

Hasil pengamatan menunjukan tinggi tanaman yang berbeda-beda antar perlakuan, yang ditunjukan pada gambar 4 berikut.

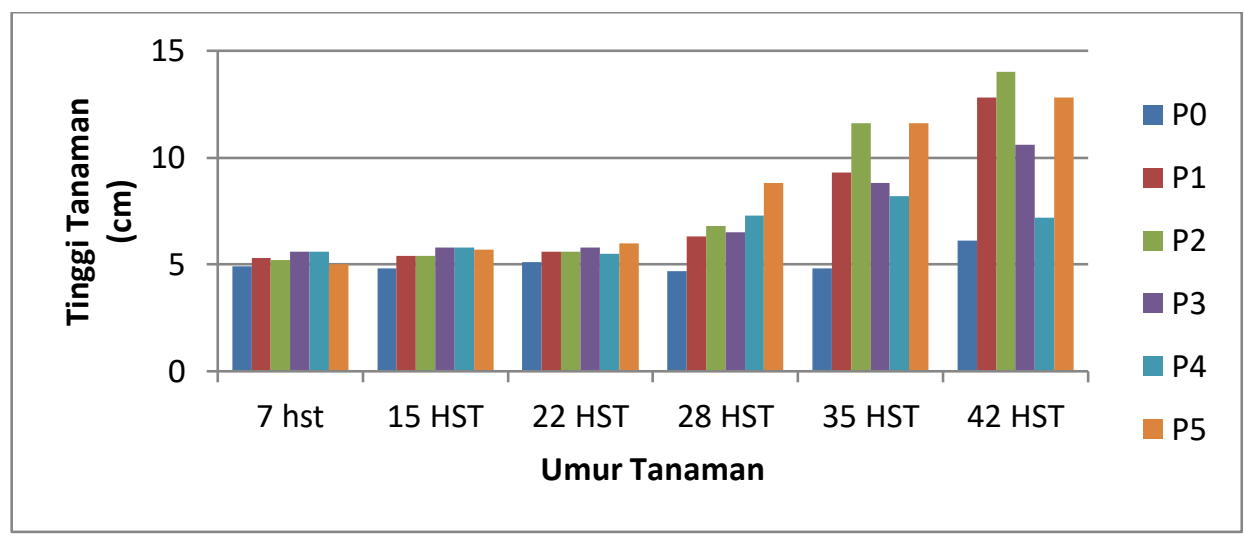

Gambar 4. Grafik Tinggi Tanaman Sawi Setiap Minggu

Hasil pengukuran menunjukan bahwa tinggi tanaman pada

umur 7 hari setelah tanam memiliki tinggi rata-rata $5.6 \mathrm{~cm}$ pada perlakukan P3 dan P4, kemudian diikuti tinggi tanaman pada perlakuan P1 yang dengan dosis nurisi $5 \mathrm{ml} / \mathrm{l}$, yaitu $5.3 \mathrm{~cm}$. Pada perlakuan $\mathrm{P} 2$ dengan dosis nutrisi $10 \mathrm{ml} / \mathrm{l}$, dengan tinggi tanaman $5.2 \mathrm{~cm}$, selanjutnya pada perlakuan P5 dengan dosis nutrisi 25 $\mathrm{ml} / \mathrm{l}$, dengan tinggi tanaman $4.9 \mathrm{~cm}$. Tinggi tanaman pada umur 42 hari setelah tanam, tinggi tanaman rata-rata yaitu $14 \mathrm{~cm}$ pada tanaman dengan perlakuan $\mathrm{P} 2$, diikuti tanaman pada perlakuan $\mathrm{P} 1$ dan P5 yaitu $12.8 \mathrm{~cm}$. Selanjutnya perlakuan P3 dengan tinggi $10.6 \mathrm{~cm}$. Perlakuan P4 dengan tinggi rata-rata tanaman $7.2 \mathrm{~cm}$. P0 sebagai control memiliki tinggi rata-rata $6.1 \mathrm{~cm}$.

Hasil analisis varians satu arah (one way anova) terhadap tinggi tanaman ditunjukan pada tabel 4. Berikut Tabel 4. Analisis Varian Tinggi Tanaman Sawi

\begin{tabular}{lrrrrrr}
\hline \multicolumn{1}{c}{ Source of Variation } & \multicolumn{1}{c}{ SS } & \multicolumn{1}{c}{ Df } & \multicolumn{1}{c}{ MS } & \multicolumn{1}{c}{ F } & P-value & F crit \\
\hline Antar Kelompok & 265.24 & 5 & 53.05 & 10.04 & 0.00 & 2.62 \\
Dalam Kelompok & 126.80 & 24 & 5.28 & & & \\
& & & & & & \\
Total & 392.04 & 29 & & & & \\
\hline
\end{tabular}

Taraf signifikansi sebesar 0.00 lebih kecil dari taraf signifikansi tetapan sebesar 0.05 , yang berarti bahwa perlakuan dosis pupuk organik cair berpengaruh nyata terhadap tinggi tanaman sawi. Hasil uji lanjut dengan uji t 2 sampel terhadap rata-rata tinggi tanaman sawi sebagai hasil perlakuan dosis pupuk 
organik cair pada sistem hidroponik wick dapat dilihat pada tabel 5 berikut.

Tabel 5. Rata-rata tinggi tanaman

\begin{tabular}{cc}
\hline Dosis Pupuk Organik Cair & Rata-Rata Tinggi Tanaman \\
\hline P0 $(0 \mathrm{ml} / \mathrm{L})$ & $6.1^{\text {acd }}$ \\
P1 $(5 \mathrm{ml} / \mathrm{L})$ & $12.8^{\text {cd }}$ \\
P2 $(10 \mathrm{ml} / \mathrm{L})$ & $14^{\mathrm{d}}$ \\
P3 $(15 \mathrm{ml} / \mathrm{L})$ & $10.6^{\text {cd }}$ \\
P4 $(20 \mathrm{ml} / \mathrm{L})$ & $7.2^{\mathrm{abcd}}$ \\
P5 $(25 \mathrm{ml} / \mathrm{L})$ & $12.8^{\text {cd }}$ \\
\hline
\end{tabular}

Ket : angka yang diikuti huruf yang sama tidak berbeda nyata pada taraf signifikansi 0.05

Hasil uji t menunjukan bahwa perlakuan dengan dosis pupuk organik cair P1,P5 tidak berbeda nyata dengan perlakuan P3 namun berbeda nyata dengan perlakuan lainnya. Perlakuan dosis pupuk organic cair P2 memberikan jumlah rata-rata daun terbanyak dan berbeda nyata dengan perlakuan-perlakuan lainnya.

\section{Jumlah Daun Tanaman Sawi}

Hasil pengamatan menunjukan jumlah daun yang berbedabeda antar masing-masing perlakuan seperti yang ditunjukan pada gambar 5 berikut.

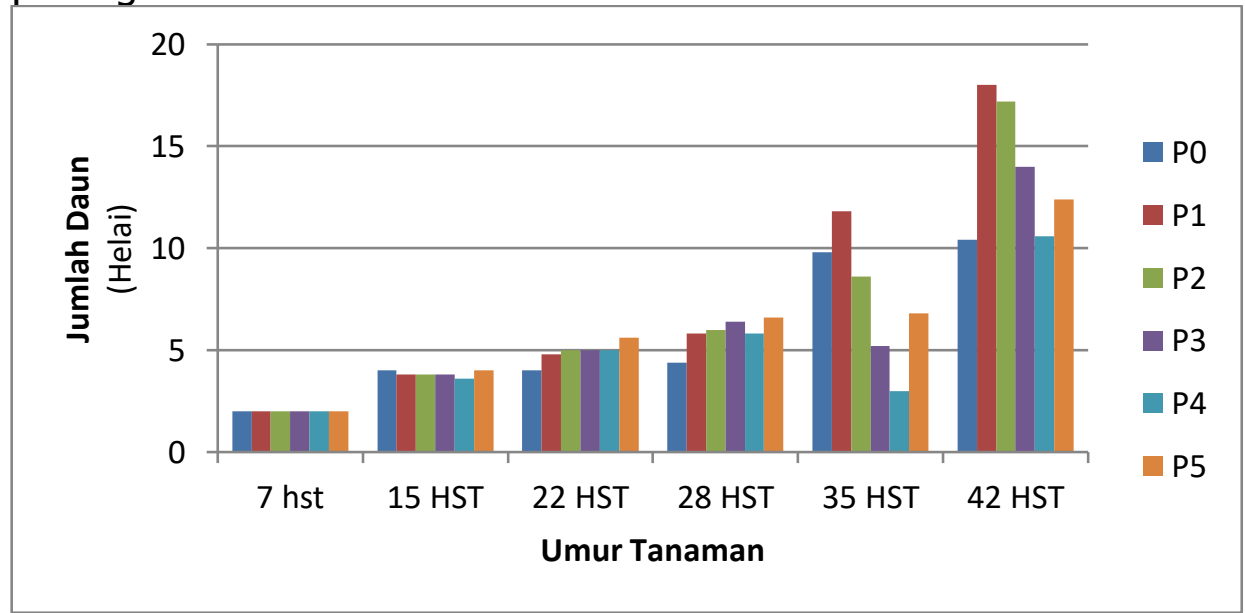

Gambar 5. Grafik Jumlah Daun Tanaman Sawi Setiap Minggu

Hasil pengukuran menunjukan bahwa tinggi tanaman pada umur 7 hari setelah tanam memiliki tinggi rata-rata yang sama untuk semua perlakuan yaitu 2 helai. Jumlah daun tanaman pada umur 42 hari setelah tanam, jumlah daun tanaman rata-rata yaitu 18 helai pada tanaman dengan perlakuan $\mathrm{P} 1$, diikuti tanaman pada perlakuan P2 yaitu 17.2 helai. Selanjutnya perlakuan P3 dengan jumlah daun 14 helai. Perlakuan P5 dengan jumlah daun rata-rata tanaman 12.4 helai. Perlakuan P4 memiliki jumlah daun 
rata-rata 10.6 helai dan dan P0 dengan jumlah daun rata-rata 10.4 helai.

Hasil analisis varians satu arah (one way anova) terhadap tinggi tanaman ditunjukan pada tabel 5. Berikut

Tabel 6. Analisis varian jumlah daun

\begin{tabular}{lcccccr}
\hline \multicolumn{1}{l}{$\begin{array}{l}\text { Source of } \\
\text { Variation }\end{array}$} & SS & $d f$ & MS & $F$ & P-value & Fcrit \\
\hline $\begin{array}{l}\text { Antar } \\
\text { Kelompok }\end{array}$ & 264.97 & 5.00 & 52.99 & 4.92 & 0.00 & 2.62 \\
$\begin{array}{l}\text { Dalam } \\
\text { Kelompok }\end{array}$ & 258.40 & 24.00 & 10.77 & & & \\
Total & 523.37 & 29.00 & & & & \\
\hline \multicolumn{1}{r}{ Taraf } & signifikansi & sebesar & 0.00 & lebih & kecil dari & taraf
\end{tabular}

signifikansi tetapan sebesar 0.05 , yang berarti bahwa perlakuan dosis pupuk organik cair berpengaruh nyata terhadap jumlah daun tanaman sawi. Hasil uji lanjut dengan uji t 2 sampel terhadap rata-rata jumlah daun tanaman sawi sebagai hasil perlakuan dosis pupuk organik cair pada sistem hidroponik wick dapat dilihat pada tabel 6 berikut.

Tabel 6. Rata-rata jumlah daun

\begin{tabular}{cc}
\hline Dosis Pupuk Organik Cair & Rata-Rata Jumlah Daun \\
\hline P0 $(0 \mathrm{ml} / \mathrm{L})$ & $10.4^{\mathrm{a}}$ \\
P1 $(5 \mathrm{ml} / \mathrm{L})$ & $18^{\mathrm{b}}$ \\
P2 $(10 \mathrm{ml} / \mathrm{L})$ & $17.2^{\mathrm{b}}$ \\
P3 $(15 \mathrm{ml} / \mathrm{L})$ & $14^{\mathrm{a}}$ \\
P4 $(20 \mathrm{ml} / \mathrm{L})$ & $10.6^{\mathrm{a}}$ \\
P5 $(25 \mathrm{ml} / \mathrm{L})$ & $12.4^{\mathrm{a}}$ \\
\hline
\end{tabular}

Ket : angka yang diikuti huruf yang sama tidak berbeda nyata pada taraf signifikansi 0.05

Hasil uji t menunjukan bahwa perlakuan dengan dosis pupuk organik cair P1 tidak berbeda nyata dengan perlakuan P3 namun berbeda nyata dengan perlakuan P0,P3,P4 dan P5.

\section{Bobot Segar}

Bobot segar untuk tanaman sawi dapat dilihat dalam gambar 6. Berikut 


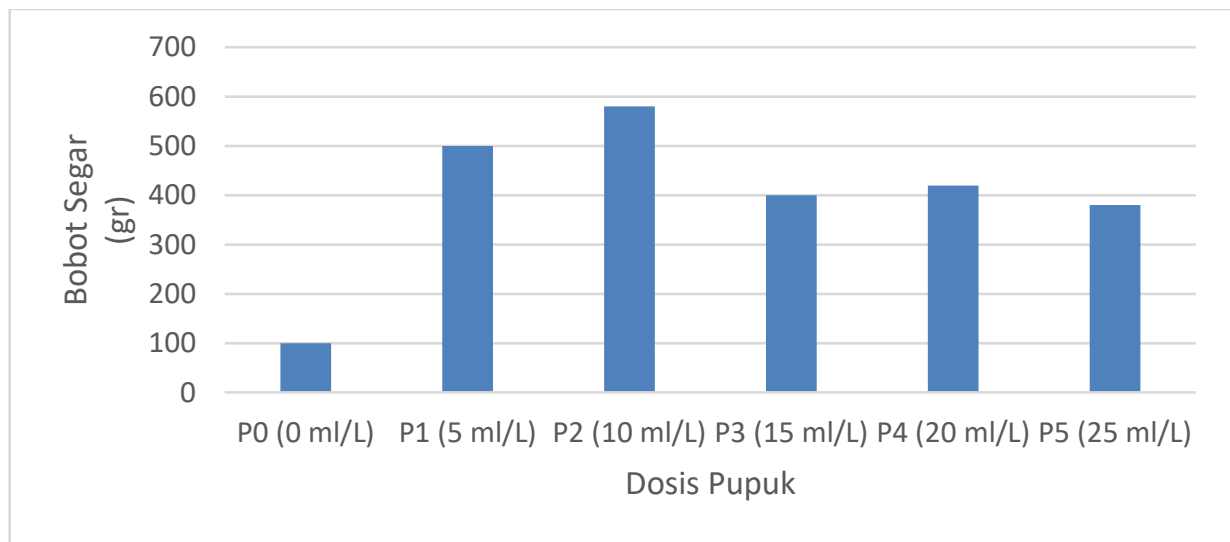

Gambar 6. Grafik bobot segar tanaman sawi

Berdasarkan gambar diatas dapat dilihat bahwa perlakuan P2 dengan dosis pupuk $10 \mathrm{ml} / \mathrm{L}$ menghasilkan bobot segar tanaman terberat dengan bobot sebesar $580 \mathrm{gr} / \operatorname{tanaman}$.

Berdasarkan hasil analisis dapat dilihat bahwa hidroponik dengan sistem sumbu dapat cocok diaplikasikan untuk tanaman sawi. Penambahan dosis pupuk cair organik berpengaruh terhadap pertumbuhan tanaman sawi. Pengaruh tersebut ditinjau dari tinggi tanaman,jumlah daun dan bobot segar tanaman. Tinggi tanaman sawi yang diberi perlakuan berbeda nyata dengan tanaman tanpa perlakuan. Tanaman yang diberi perlakuan memiliki rata-rata tertinggi jika dibandingkan dengan tanaman tanpa perlakuan. Hal ini disebabkan oleh pertumbuhan tinggi tanaman berhubungan dengan letak meristem apikal. Meristem apikal terdapat di ujung akar dan diujung tunas yang menghasilkan pemanjangan bagi selsel tumbuhan (Campbell, 2003). Tanaman yang kekurangan unsur hara $\mathrm{N}$ dan $\mathrm{K}$ akan menurunkan produksi tanaman dan membuat tanaman menjadi kerdil (Franklin dan Cleon, 1995).

Berat basah pada tanaman sawi terbaik pada penelitian ini adalah pada tanaman dengan perlakuan P2 dengan dosis $10 \mathrm{ml} / \mathrm{L}$ yaitu seberat $580 \mathrm{gr}$. Pada perlakuan ini, tinggi tanaman sawi relative lebih tinggi dan jumlah daun yang tidak berbeda nyata dengan perlakuan yang lainnya. El-vivo dalam Veronica (2015) mengemukakan bahwa daun merupakan tempat terjadinya fotosintesis, apabila fotositesis berjalan dengan baik maka fotosintesis yang dihasilkan juga banyak yang nantinya digunakan untuk pembentukan organ dan jaringan dalam tanaman, seperti batang dan daun sehingga bobot tanaman semakin berat. Nutrisi yang tepat akan memberikan hasil optimal pada pertumbuhan tanaman. Lestari (2009), mengemukakan bahwa nutrisi yang diberikan pada tanaman harus tepat, jika kekurangan atau 
kelebihan akan mengakibatkan pertumbuhan tanaman dan hasil produksi kurang maksimal.

\section{Kesimpulan dan Saran \\ Kesimpulan}

Berdasarkan hasil penelitian dapat disimpulkan bahwa Hidroponik wick system dapat diaplikasikan pada tanaman kangkung dan sawi dengan dosis pemberian nutrisi pada tanaman kangkung sebesar $20 \mathrm{ml} / \mathrm{L}$ dan $10 \mathrm{ml} / \mathrm{L}$ untuk tanaman sawi.

\section{Saran}

Diperlukan penelitian pada sistem hidroponik wick system dengan menggunakan media tanam selain arang sekam dan cocopeat .

\section{Daftar Pustaka}

Artha, T. 2014. Interaksi Pertumbuhan antara Shorea selanica dan Gnetum gnemon dalam Media Tanam dengan Konsentrasi Cocopeat yang Berbeda. Skripsi. Institut Pertanian Bogor. Bogor. $25 \mathrm{hlm}$.

Campbell et al, Biologi Edisi ke5- Jilid2, Erlangga, Jakarta, 2003,. h.34.

Franklin.B Salisburry dan Cleon W Rpss, Fisiologi Tumbuhan, Jilid 3, ITB, Bndung, 1995), h.7

Muliawan, L. 2009. Pengaruh Media Semai Terhadap Pertumbuhan Pelita (Eucalyptus pellita F.Muell). Skripsi. Institut Pertanian Bogor. Bogor. $104 \mathrm{hlm}$.

Kusnadi, N., N.Tinaprilla, S.H.Susilowati, dan A.Purwoto. Analisis Efisiensi Usahatani Padi di Beberapa Sentra Produksi Padi di Indonesia. Jurnal Agro Ekonomi. 29 (1) : 25 - 48. (Untuk jurnal)

Oktavia, F., 2013. Peran Produk Olahan Sabut Kelapa Sebagai Penunjang Kelestarian Ekologi. Prosiding Konferensi Nasional Kelapa VIII. 21 Mei 2014, Jambi, Indonesia. Hal. 205 - 210. (Untuk prosiding)

Veranica In Haryanto, Supriyono, dan Samanhudi,"Pemanfaatan Limbah Cair Industri Tepung Aren dan Mikroorganisme Lokal Sebagai Larutan Nutrisi Terhadap Pertumbuhan dan Hasil Tanaman Bay Kailan (Brassica oleracea) Dengan Sistem Hidroponik", Jurnal EL-VIVO Vol.3, No,2, ISSN: 2339-1901, (September 2015), h.78 